\title{
Developmental dyslexia: an update
}

\author{
Barkur S. Shastry
}

Received: 26 October 2006/ Accepted: 30 October 2006/Published online: 17 November 2006

(C) The Japan Society of Human Genetics and Springer 2006

\begin{abstract}
Dyslexia is the most common and carefully studied of the learning disabilities in school-age children. It is characterized by a marked impairment in the development of reading skills, and affects a large number of people (5-10\%). Reading difficulties may also arise from poor vision, emotional problems, decreased hearing ability, and behavioral disorders, such as attention-deficit hyperactivity (ADHD). Although many areas of the brain are involved in reading, analysis of postmortem brain specimens by a variety of imaging techniques most consistently suggests that deficiency within a specific component of the language system-the phonologic module-in the temporo-parietal-occipital brain region underlies dyslexia. It is a highly familial and heritable disorder with susceptibility loci on chromosomes 1, 2, 3, 6, 11, 13, 15 and 18 . Recently, four candidate genes (KIAA 0319, DYX1C1, DCDC2 and ROBO1) are shown to be associated with dyslexia. Although some of these results are controversial because of the genetic heterogeneity of the disorder, the available evidence suggests that dyslexia could be due to the abnormal migration and maturation of neurons during early development. Interestingly, in spite of genetic heterogeneity, the pathology appears to involve common phonological coding deficits. The condition can be managed by a highly structured educational training exercise.
\end{abstract}

Keywords Gene $\cdot$ Linkage $\cdot$ Orthography $\cdot$ Phonology

B. S. Shastry $(\bowtie)$

Department of Biological Sciences,

Oakland University, Rochester,

MI 48309, USA

e-mail: shastry@oakland.edu

\section{Introduction}

Developmental dyslexia (DD), which is also known as specific reading disability, is a complex cognitive disorder. It is perhaps the most common neurobehavioral condition and the most carefully studied of the childhood learning disabilities. The disorder affects a large number of people, and its prevalence in school age children is approximately 5-10\% (Shaywitz et al. 1990, 1992; Pennington 1990). It is a persistent chronic condition and the affected individuals do not have defects in vision or hearing, although these deficits may also affect reading ability. They also do not have acquired neurological problems but have normal intelligence and school attendance. Although previous studies suggested that dyslexia affects both males and females equally (Rumsey 1992), recent reports indicate that it is more common in boys than in girls (Rutter et al. 2004; Liederman et al. 2005). It has a recurrence risk of approximately 4.52 for spelling and reading, as demonstrated by single proband sib-pair design, and a one standard deviation discrepancy criterion (Ziegler et al. 2005a). The clinical features of dyslexia may overlap with other disorders, such as language learning disability (Vicari et al. 2005; Ziegler et al. 2005b), alexia (acquired reading disorder), hyperlexia, and attentiondeficit hyperactivity disorder (ADHD). However, none of these disorders involve phonologic deficits similar to dyslexia (Shaywitz 1998).

\section{Neurobiological studies}

In dyslexia, the affected individuals are unable to read words accurately (decoding), and the mechanism of this 
impairment is unknown. In many children, reading difficulty may improve over time but impairment in spelling remains affected. However, it should be remembered that many dyslexic patients are successful in a variety of professional disciplines, such as law, medicine, science and education. There are a number of theories that have been proposed for the disorder. These are called auditory processing, cerebellar, visual, and phonological theory (Petkov et al. 2005; Ramus et al. 2003). In accordance with these theories, neurological evaluation demonstrated deficit in verbal memory, language and phonological coding (ability to explicitly recognize individual phonemes in words), suggesting the involvement of the left hemisphere (Rumsey 1992). A minority of dyslexic children have particular difficulty with the phonological auditory channel and slow speed of processing in verbal and non-verbal tasks (MillerShaul 2005; Boets et al. 2006). In addition, a subgroup of dyslexic children exhibit visual perceptual deficits, but therapies aimed to improve perception are unsubstantiated. There is also a difference between familial and typically developing infants in productive language patterns (Koster et al. 2005). Additionally, a multiple sensory system involvement as well as differences in reading deficits between adults and children has been reported (Hairston et al. 2005; Osmon et al. 2005). Dyslexic patients may also have impaired balancing skills, low-level sensory and motor learning deficits, and cerebellar dysfunction (Stoodley et al. 2005; 2006).

Because of the limited availability of postmortem brain specimens and its non-life-threatening nature, only limited information on the neuropathology of dyslexia is available. Although many areas of the brain are involved in reading, neurobiological studies of brain specimens, using functional magnetic resonance imaging, diffusion tensor imaging and brain morphometry techniques, suggest the dysfunction of left temporoparieto-occipital brain regions in dyslexia (Eckert et al. 2005; Rumsey 1992; Shaywitz 1998; Shaywitz and Shaywitz 2005; Donfrancesco et al. 2005). These regions are known to perform phonemic analysis and conversion of written symbols to phonological units of speech. Consistent with the above finding is the observation that the development of fluent reading in children can be correlated with the altered density of gray and white matter structure in the left temporal parietal region (Deutsch et al. 2005; Silani et al. 2005). Interestingly, this neurological abnormality is the same across cultures. Thus, it has been commonly agreed that a dysfunction in phonological processes (Fosker and Thierry 2005; Elbro and Jensen 2005) that involve the left temporo-parietal brain region may determine developmental dyslexia. This region may be involved in analyzing the written word. However, this cannot be a universal theory because there is no deficit in the posterior-temporal brain region in Chinese dyslexic patients (Siok et al. 2004; Ziegler 2006). Instead, there is a functional disruption of the left middle frontal gyrus. In general, during reading, it is believed that information from the association cortex of the occipital lobe is transferred to the angular gyrus and then to the superior temporal gyrus which is critical to phonological coding (Henderson 1986). Thus, it appears that properties of the script and the type of task may determine the reading problems even if there is a common region involved (Ziegler et al. 2003; Raman and Weekes 2005). Moreover, the above study also suggests that biological reading deficits may depend on culture. Additional studies indicate that a letter processing impairment, which is due to the serial encoding of letters (Rayner and Johnson 2005), may be the fundamental cause of the disorder (Fiset et al. 2005; Arguin and Bub 2005). Both cerebral hemispheres contain phonological, orthographic (knowledge of which letters occur together) and semantic representation of words. However, both of these hemispheres are not functionally equal and that may explain the differences between people with dyslexia (Lavidor et al. 2006). In addition, differences in the locus of cerebellar impairment may be responsible for subtypes of dyslexia, such as developmental surface and developmental deep dyslexia (Shu et al. 2005; Nocolson and Fawcett 2005).

Reading consists of two main basic processes: decoding and comprehension. There is a strong consensus among investigators in the field that deficiency within a specific component of the language system-the phonologic module-underlies dyslexia. This phonological awareness is strongly heritable. In dyslexia, because of the impairment in the phonologic module, patients are unable to decode and identify the word (Shaywitz 1998). An additional more consistent finding in dyslexia is the lack of planum temporale asymmetry that is important for language function. It has been hypothesized that this symmetry is due to reduced cell death during fetal development (Galabnrda et al. 1985; Paul et al. 2006). This may result in an excess of neurons in the right planum that may contribute to miswiring of the brain. It is also possible that in dyslexics cortical auditory processing may be differently organized.

\section{Genetics}

As discussed above, dyslexia is a disorder within the language system, in particular phonological processing. 
It is highly familial and heritable, but the pathophysiology and mode of transmission of DD are not known. There may be two types of reading impairments: one could be due to genetics and the other to environmental influences (Shaywitz and Shaywitz 2005). There is strong evidence (affected parent) for a genetic contribution to the disorder. According to twin studies, only certain reading related skills (phonological aspects of reading accuracy) are inherited and the heritability of the disorder is approximately 0.71 (Pennington et al. 1991; Schulte-Korne 1996; DeFries et al. 1987). When children of consanguineous marriages were examined for their reading disabilities, the rate of reading disabilities is higher in children of firstcousin parents than that of second-cousin or unrelated parents. This suggests a genetic basis of reading disabilities (Abu-Rabia and Maroun 2005). Genetic linkage and association studies have reported several susceptibility loci on chromosomes 1p (DYX8), 2p (DYX3), 3p (DYX5), 6p (DYX2), 11p (DYX7), 15q (DYX1), 18p (DYX6), and Xq27.3 (DYX9) (Rabin et al. 1993; Grigorenko et al. 2001, 2003, 1997; Tzenova et al. 2004; Fagerheim et al. 1999; Francks et al. 2002; Kaminen et al. 2003; Chapman et al. 2004; Cardon et al. 1994; Fisher et al. 1999, 2002 Kaplan et al. 2002; Turic et al. 2003; Schulte-Korne et al. 1998; Morris et al. 2000; Marlow et al. 2003; Hsiung et al. 2004). Recently, a genome-wide scan also identified the chromosome 13 locus for subphenotypes of dyslexia (Igo et al. 2006).

Among these chromosomes, a region on chromosome $6 \mathrm{p}$ is most consistently supported in a number of independent samples. Recently, it was shown that a variation in the KIAA 0319 gene on chromosome $6 p$ is associated with dyslexia (Cope et al. 2005; Franks et al. 2004). This gene is highly expressed in the brain but its function is unknown. Its structural analysis shows homology to the extracellular domains of the protein PKD1 which are involved in cell adhesive functions (Streets et al. 2003). A second gene, DCDC2 (doublecortin domain-containing 2 which may be involved in cortical neuron migration) from the $6 \mathrm{p} 22$ region, has also been proposed as a candidate gene (Meng et al. 2005b; Schumacher et al. 2006a). In affected dyslexic individuals, a short stretch of DNA within the DCDC2 gene is deleted and the gene is highly expressed in fetal and adult brain regions. A third candidate gene, located on chromosome 15q (DYX1), was also found to be associated with dyslexia in a cohort from Finland. This gene, known as DYX1C1, is disrupted by the translocation, and two variants $(-3 \mathrm{G} \rightarrow \mathrm{A}$ and $1,249 \mathrm{G} \rightarrow \mathrm{T})$ are associated with dyslexia. It is also expressed in human glial and neuronal cells but its function is not known. However, this result is not replicated in a twin cohort and a family-based association study by other investigators (Marino et al. 2005; Meng et al. 2005a; Bellini et al. 2005). To resolve this discrepancy, either more studies are needed or this discrepancy could be due to genetic heterogeneity of dyslexia in different populations. It is also not associated with other language related disorders such as autism (Ylaisaukko-oja et al. 2005). Additionally, in one large family, a fourth candidate gene that codes for an axon guidance receptor gene (ROBO1), which is orthologous to the drosophila roundabout gene (involved in neuronal connections between the two sides of the brain), is found to be disrupted by a chromosome translocation. This result is replicated in the German population but not in British populations. The above results may suggest that genes involved in neuronal migration and maturation during early development may play an important role in dyslexia (HannulaJouppi et al. 2005). Interestingly, in spite of genetic heterogeneity in dyslexia, there appears to be a common phonological coding deficit in affected individuals.

\section{Concluding remarks}

One of the learning disabilities in school-aged children is the reading disorder that is also known as dyslexia. Reading difficulties may arise from poor vision, emotional problems, behavioral disorders such as ADHD, and decreased hearing ability. Although children with DD have adequate motivation and intelligence, they have substantially low-level reading achievement compared to what would be expected for that age level. They have difficulties in reading and spelling. Hence, it is a disorder within the language system and, in particular, phonological processing. A variety of neurobiological studies with postmortem brain specimens suggest the involvement of the temporo-parietooccipital brain region in dyslexia. It is a highly heritable and genetically heterogeneous disorder and several susceptibility loci have been reported. This includes chromosomes 1, 2, 3, 6, 11, 13, 15, and 18. Among these, chromosome $6 \mathrm{p}$ is most consistently supported by a number of independent samples. Recently, it was shown that a variant in a gene on chromosome $6 p$ is associated with dyslexia. However, its replication awaits further studies. Similarly, the largest genome wide linkage reported to date is chromosome 18 which has been described as having the strongest influences on single word reading. However, a recent finding disputes this observation. The discrepancy could be due to limited power of the study and differences in 
study design (Schumacher et al. 2006b). Dyslexia can be managed by a highly structured educational training exercise, such as segmenting a spoken word into its individual sounds or identifying rhyming and nonrhyming words. In addition, providing extra time for reading, laptop computers, tape recorders, access to lecture notes in the class, and tutors may accommodate dyslexic students.

\section{References}

Abu-Rabia S, Maroun L (2005) The effect of consanguineous marriage on reading disability in the Arab community. Dyslexia 11:1-21

Arguin M, Bub D (2005) Parallel processing blocked by letter similarity in letter-by-letter dyslexia: a replication. Cogn Neuropsychol 22:589-602

Boets B, Wouters J, van Wieringen A, Ghesquiere P (2006) Auditory temporal information processing in preschool children at family risk for dyslexia: relations with phonological abilities and developing literacy skills. Brain Lang 97:64-79

Bellini G, Bravaccio C, Calamoneri F, Donatella CM, Fiorillo P, Gagliano A, Mazzone D, Del Giudice EM, Scuccimarra G, Militerni R, Pascotto A (2005) No evidence for association between dyslexia and DYX1C1 functional variants in a group of children and adolescents from southern Italy. J Mol Neurosci 27:311-314

Cardon LR, Smith SD, Fulker DW, Kimberling WJ, Pennington BF, DeFries JC (1994) Quantitative trait locus for reading disability on chromosome 6 . Science 266:276-279

Chapman NH, Igo RP, Thomson JB, Matsushita M, Brkanac Z, Holzman T, Berninger V. W, Wijsman EM, Raskind WH (2004) Linkage analysis of four regions previously implicated in dyslexia confirmation of a locus on chromosome 15q. Am J Med Genet B 131:67-75

Cope N, Harold D, Hill G, Moskvina V, Stevenson J, Holmans P, Owen MJ, O'Donovan MC, Williams J (2005) Strong evidence that KIAA0319 on chromosome 6p is a susceptibility gene for developmental dyslexia. Am J Hum Genet 76:581-591

DeFries JC, Fulker DW, LaBuda MC (1987) Evidence for a genetic etiology in reading disability of twins. Nature 329:537-539

Deutsch GK, Dougherty RF, Bammer R, Siok WT, Gabrieli JD, Wandell B (2005) Children's reading performance is correlated with white matter structure measured by diffusion tensor imaging. Cortex 41:354-363

Donfrancesco R, Mugnaini D, Dell'uomo A (2005) Cognitive impulsivity in specific learning disabilities. Eur Child Adolesc Psychiatry 14:270-275

Eckert MA, Leonard CM, Wilke M, Eckert M, Richards T, Richards A, Berninger V (2005) Anatomical signatures of dyslexia in children: unique information from manual and voxel based morphometry brain measures. Cortex 41:304-315

Elbro C, Jensen MN (2005) Quality of phonological representations, verbal learning, and phoneme awareness in dyslexia and normal readers. Scand J Psychol 46:375-384

Fagerheim T, Raeymaekers P, Tonnessen FE, Pedersen M, Tranebjerg L, Lubs HA (1999) A new gene (DYX3) for dyslexia is located on chromosome 2. J Med Genet 36:664669
Fiset D, Arguin M, Bub D, Humphreys GW, Riddoch MJ (2005) How to make the word-length effect disappear in letter-byletter dyslexia. Psychol Sci 16:535-541

Fisher SE, Marlow AJ, Lamb J, Maestrini E, Williams DF, Richardson A J, Weeks DE, Stein JF, Monaco AP (1999) A quantitative trait locus on chromosome $6 \mathrm{p}$ influences different aspects of developmental dyslexia. Am J Hum Genet 64:146-156

Fisher SE, Franks C, Marlow AJ, MacPhie IL, Newbury DF, Cardon LR, Ishikawa-Brush Y, Richardson AJ, Talcott JB, Gayan J, Olson RK, Pennington BF, Smith SD, DeFries JC, Stein JF, Monaco AP (2002) Independent genome-wide scans identify a chromosome 18 quantitative trait locus influencing dyslexia. Nat Genet 30:86-91

Fosker T, Thierry G (2005) Phonological oddballs in the focus of attention elicit a normal P3b in dyslexic adults. Brain Res Cogn Brain Res 24:467-475

Francks C, Fisher SE, Olson RK, Pennington BF, Smith SD, DeFries JC, Monaco AP (2002) Fine mapping of the chromosome 2p12-16 dyslexia susceptibility locus: quantitative association analysis and positional candidate genes SEMA 4F and OTX1. Psychiatr Genet 12:35-41

Franks C, Paracchini S, Smith SD, Richardson AJ, Scerri TS, Cardon LR, Marlow AJ, MacPhie L, Water J, Pennington BF, Fisher SE, Olson RK, DeFries JC, Stein JF, Monaco AP (2004) A 77-kilobase region of chromosome 6p22.2 associated with dyslexia in families from the United Kingdom and from the United States. Am J Hum Genet 75:1046-1058

Galabnrda AM, Sherman GP, Rosen GD, Aboitiz F, Geschwind N (1988) Developmental dyslexia: four consecutive patients with cortical anomalies. Ann Neurol 18:222-233

Grigorenko EL, Wood FB, Meyer MS, Hart LA, Speed WC, Shuster A, Pauls DL (1997) Susceptibility loci for distinct components developmental dyslexia on chromosomes 6 and 15. Am J Hum Genet 60:27-39

Grigorenko EL, Wood FB, Meyer MS, Pauls JED, Hart LA, Pauls DL (2001) Linkage studies suggest a possible locus for developmental dyslexia on chromosome 1p. Am J Med Genet 105:120-129

Grigorenko EL, Wood FB, Golovyan L, Meyer M, Romano C, Pauls D (2003) Continuing the search for dyslexia gene on 6p. Am J Med Genet B Neuropsychiatr Genet 118:89-98

Hairston WD, Burdette JH, Flowers DL, Wood FB, Wallace MT (2005) Altered temporal profile of visual-auditory multisensory interactions in dyslexia. Exp Brain Res 166:474-480

Hannula-Jouppi K, Kaminen-Ahola N, Taipale M, Eklund R, Nopola-Hemmi J, Kaariainen H, Kere J (2005) The axon guidance receptor gene ROBO1 is a candidate gene for developmental dyslexia. PLoS Genet 1:467-474

Henderson VW (1986) Anatomy of posterior pathways in reading: a reassessment. Brain Lang 29:119-133

Hsiung GY, Kaplan BJ, Petryshen TL, Lu S, Field L (2004) A dyslexia susceptibility locus (DYX7) linked to dopamine D1 receptor (DRD4) region on chromosome 11p15.5. Am J Med Genet 125B:112-119

Igo RP Jr, Chapman NH, Berninger VW, Matsushita M, Brkanac Z, Rothstein JH, Holzman T, Nielsen K, Raskind WH, Wijsman EM (2006) Genome-wide scan for real-word reading subphenotypes of dyslexia: novel chromosome 13 locus and genetic complexity. Am J Med Genet B Neuropsychiatr Genet 141:15-27

Kaminen N, Hannula-Jouppi K, Kestila M, Lahermo P, Muller K, Kaaranen M, Myllyluoma B, Voutilainen A, Lyytinen H, Nopola-Hemmi J, Kere J (2003) A genome scan for developmental dyslexia confirmed linkage to chromosome 2p11 and suggests a new locus on 7q32. J Med Genet 40:340-345 
Kaplan DE, Gayan J, Ahn J, Won TW, Pauls D, Olson RK, DeFries JC, Wood F, Pennington BF, Page GP, Smith SD, Gruen JR (2002) Evidence for linkage and association with reading disability on 6p21.3-22. Am J Hum Genet 70:12871298

Koster C, Been PH, Krikhaar EM, Zwarts F, Diepstra HD, Van Leeuwen TH (2005) Differences at 17 months: productive language patterns in infants at familial risk for dyslexia and typically developing infants. J Speech Lang Hear Res 48:426-438

Lavidor M, Johnston R, Snowling MJ (2006) When phonology fails: orthographic neighbourhood effects in dyslexia. Brain Lang 96:318-329

Liederman J, Kantrowitz L, Flannery K (2005) Male vulnerability to reading disability is not likely to be a myth: a call for new data. J Learn Disabil 38:109-129

Marino C, Giorda R, Lorusso ML, Vanzin L, Salandi N, Nobile M, Citterio A, Beri S, Crespi V, Battagila M, Molteni M (2005) A family-based association study does not support DYX1C1 on 15q21.3 as a candidate gene in developmental dyslexia. Eur J Hum Genet 13:491-499

Marlow AJ, Fisher SE, Franks C, MacPhie IL, Cherny SS, Richardson AJ, Talcott JB, Stein JF, Monaco AP, Cardon LR (2003) Use of multivariate linkage analysis for dissection of a complex cognitive trait. Am J Hum Genet 72:561-570

Meng H, Hager K, Held M, Page GP, Olson RK, Pennington BF, Defries JC, Smith SD, Gruen JR (2005a) TDT-association analysis of EKN1 and dyslexia in a Colorado twin cohort. Hum Genet 118:87-90

Meng H, Smith SD, Hager K, Held M, Liu J, Olson RK, Pennington BF, Defries JC, Gelernter J, O'reilly-Pol T, Somlo S, Skudlarski P, Shaywitz SE, Shaywitz BA, Marchione K, Wang Y, Paramasivam M, Loturco JJ, Page GP, Gruen JR (2005) DCDC2 is associated with reading disability and modulates neuronal development in the brain. Proc Nat Acad Sci USA 102:17053-17058

Miller-Shaul S (2005) The characteristics of young and adult dyslexies readers on reading and reading related cognitive tasks as compared to normal readers. Dyslexia 11:132-151

Morris DW, Robinson L, Turic D, Duke M, Webb V, Milham C, Hopkin E, Pound K, Fernando S, Easton M, Hamshere M, Williams N, McGuffin P, Stevenson J, Krawczak M, Owen MJ, O'Donovan MC, Williams J (2000) Family based association mapping provides evidence for a gene for reading disability on chromosome 15q. Hum Mol Genet 9:843-848

Nocolson RI, Fawcett AJ (2005) Developmental dyslexia, learning and the cereberllum. J Neural Transm Suppl 69:19-36

Osmon DC, Braun MM, Plambeck EA (2005) Processing abilities associated with phonologic and orthographic skills in adult learning disability. J Clin Exp Neuropsychol 27:544554

Paul I, Bott C, Heim S, Eulitz C, Elbert T (2006) Reduced hemisperic asymmetry of the auditory $\mathrm{N} 260 \mathrm{~m}$ in dyslexia. Neuropsychologia 44:785-794

Petkov CL, O'Connor KN, Benmoshe G, Baynes K, Sutter ML (2005) Auditory perceptual grouping and attention in dyslexia. Brain Res Cogn Brain Res 24:343-354

Pennington BF, Gilger JW, Pauls D, Smith SA, Smith SD, DeFries JC (1991) Evidence for a major gene transmission of developmental dyslexia. JAMA 266:1527-1534

Pennington BF (1990) Annotation: The genetics of dyslexia. J Child Psychol Psychiatry 31:193-201

Rabin M, Wen XL, Hepburn M, Lubs HA (1993) Suggestive linkage of developmental dyslexia to chromosome 1p34p36. Lancet 342:178
Raman I, Weekes BS (2005) Acquired dyslexia in a TurkishEnglish speaker. Ann Dyslexia 55:79-104

Ramus F, Rosen S, Dakin S, Day B, Castellote J, White S, Frith U (2003) Theories of development al dyslexia: insight from a multiple case study of dyslexic adults. Brain 126:841-865

Rayner K, Johnson RL (2005) Letter-by-letter acquired dyslexia is due to the serial encoding of letters. Psychol Sci 16:530 534

Rumsey JM (1992) The biology of developmental dyslexia. JAMA 268:912-915

Rutter M, Caspi A, Fergusson D, Horwood J, Goodman R, Maughan B, Moffitt TE, Meltzer H, Carroll J (2004) Sex differences in developmental reading disability. JAMA 291:2007-2012

Schulte-Korne G, Deimel W, Muller K, Gutenbrunner C, Remschmidt H (1996) Familial aggregation of spelling disability. J Child Psychol Psychiatry 37:817-822

Schulte-Korne G, Grimm T, Nothen MM, Muller-Myhsok B, Cichon S, Vogt IR, Propping P, Remschmidt H (1998) Evidence for linkage of spelling disability to chromosome 15. Am J Hum Genet 63:279-282

Schumacher J, Konig IR, Plume E, Propping P, Warnke A, Manthey M, Duell M, Kleensang A, Repsilber D, Preis M, Remschmidt H, Ziegler A, Nothern MM, Schulte-Korne G (2006a) Linkage analysis of chromosomal region 18p11-q12 in dyslexia. J Neural Transm 113:417-423

Schumacher J, Anthoni H, Dahdouh F, Konig IR, Hillmer AM, Kluck N, Manthey M, Plume E, Warnke A, Remschmidt H, Hulsmann J, Cichon S, Lindgren CM, Propping P, Zucchelli M, Ziegler A, Peyrard-Janvid M, Schulte-Korne G, Nothen MM, Kere J (2006b) Strong genetic evidence of DCDC2 as a susceptibility gene for dyslexia. Am J Hum Genet 78:5262

Shaywitz SE, Shaywitz BA, Fletcher JM, Estabar MD (1990) Prevalence of reading disability in boys and girls. JAMA 264:998-1002

Shaywitz BA, Fletcher JM, Holahan JM, Shaywitz SE (1992) Discrepancy compared to low achievement definition of reading disability. J Learn Disabil 25:634-648

Shaywitz SE (1998) Dyslexia. N Engl J Med 338:307-312

Shaywitz SE, Shaywitz BA (2005) Dyslexia (specific reading disability). Biol Psychiatry 57:1301-1309

Shu H, Meng X, Chen X, Luan H, Cao F (2005) The subtypes of developmental dyslexia in Chinese: evidence from three cases. Dyslexia 11:311-329

Silani G, Frith U, Demonet JF, Fazio F, Perani D, Price C, Frith CD, Paulesu E (2005) Brain abnormalities underlying altered activation in dyslexia: a voxel based morphometry study. Brain 128:2453-2461

Siok WT, Perfetti CA, Jin Z, Tan LH (2004) Biologicalabnormality of impaired reading is constrained by culture. Nature431:71-76

Stoodley CJ, Fawcett AJ, Nicolson RI, Stein JF (2005) Impaired balancing ability in dyslexic children. Exp Brain Res 26:1-11

Stoodley CJ, Harrison EP, Stein JF (2006) Implicit motor learning deficits in dyslexic adults. Neuropsychologia 44:795-798

Streets AJ, Newby LJ, O'Hare MJ, Bukanov NO, IbraghimovBeskrovnaya O, Ang AC (2003) Functional analysis of PKD1 transgenic lines reveals a direct role for polycystin-1 in mediating cell-cell adhesion. J Am Soc Nephrol 14:18041805

Turic D, Robinson L, Duke M, Morris DW, Webb V, Hamshere M, Milham C, Hopkin E, Pound K, Fernando S, Grierson A, Easton M, Williams N, Van Den Bee M, Chowdhury R, Gruen J, Stevenson J, Krawczak M, Owen 
MJ, O’Donovan MC, Williams J (2003) Linkage disequilibrium mapping provides further evidence of a gene for reading disability on chromosome 6p21.3-22. Mol Psychiatry $8: 176-185$

Tzenova J, Kaplan BJ, Petryshen TL, Field LL (2004) Confirmation of a dyslexia susceptibility locus on chromosome 1p34-p36 in a set of 100 Canadian families. Am J Med Genet B Neuropsychiatr Genet 127:117-124

Vicari S, Finzi A, Menghini D, Marotta I, Baldi S, Petrosini L (2005) Do children with developmental dyslexia have an implicit learning deficit? J Neurol Neurosurg Psychiatry 76:1392-1397

Ylaisaukko-oja T, Peyrard-Janvid M, Lindgren C, Rehnstrom K, Vanhala R, Peltonen L, Jarvela I, Kere J (2005) Familybased association study of DYX1C1 variants in autism. Eur J Hum Genet 123:127-130
Ziegler JC, Perry C, Ma-Wyatt A, Ladner D, Schulte-Korne G (2003) Developmental dyslexia in different languages: language-specific or universal? J Exp Child Psychol 86:169-193

Ziegler A, Konig IR, Deimel W, Plume E, Nothen MM, Propping P, Kleensang A, Muller-Myshok B, Warnke A, Remschmidt H, Schulte-Korne G (2005a) Developmental dyslexia-recurrence risk estimates from a German bicenter study using the single proband sib pair design. Hum Hered 59:136-143

Ziegler JC, Pech-Georgel C, George F, Alario FX, Lorenzi C (2005b) Deficits in speech perception predict language learning impairment. Proc Natl Acad Sci USA 102:14110 14115

Ziegler JC (2006) Do differences in brain activation challenge universal theories of dyslexia. Brain Lang 98:341-343 